\title{
A longitudinal study investigating the prevalence of Staphylococcus aureus genotype $B$ in seasonally communal dairy herds
}

\author{
V. Voelk, ${ }^{*}$ H. U. Graber,† B. H. P. van den Borne, $\ddagger$ C. Sartori,§ A. Steiner, ${ }^{*}$ M. Bodmer, ${ }^{* 1,2}$ \\ and M. C. Haerdi-Landerer $\S^{1}$ \\ ${ }^{*}$ Clinic for Ruminants, Department of Clinical Veterinary Medicine, Vetsuisse Faculty, University of Berne, 3012 Berne, Switzerland \\ †Agroscope Liebefeld-Posieux Research Station ALP, 3003 Berne, Switzerland \\ †Veterinary Public Health Institute, Vetsuisse Faculty, University of Berne, 3097 Liebefeld, Switzerland \\ §Institute of Agricultural Sciences (IAS), ETH Zurich, 8092 Zurich, Switzerland
}

\begin{abstract}
Staphylococcus aureus is a major mastitis-causing pathogen. Various genotypes have been recently identified in Switzerland but Staph. aureus genotype B (GTB) was the only genotype associated with high within-herd prevalence. The risk of introducing this Staph. aureus genotype into a herd may be increased by frequent animal movements. This may also be the case when cows from different herds of origin are commingled and share their milking equipment for a limited period of time. The aim of the present study was to determine the prevalence of Staph. aureus GTB in seasonally communal dairy herds before and after a summer period when dairy farming is characterized by mixing cows from different herds of origin in 1 communal operation. In addition, the environment was investigated to identify potential Staph. aureus GTB reservoirs relevant for transmission of the disease. A total of 829 cows from 110 herds of origin in 9 communal operations were included in the study. Composite milk samples were collected from all cows during the first or second milking after arrival at the communal operation and again shortly before the end of the season. Swab samples from the environment, involved personnel, and herding dogs present were collected before the cows arrived. At the end of the season, sampling of personnel was repeated. All samples were analyzed for the presence of Staph. aureus GTB using an established quantitative PCR. At the beginning of the season, Staph. aureus GTB-positive cows were identified in 7 out of 9 communal operations and the within-communal operation prevalence ranged from 2.2 to $38.9 \%$. At the second sampling, all communal operations were Staph. aureus GTB positive, showing within-communal operation prevalence from 1 to $72.1 \%$. The between-herd of origin
\end{abstract}

Received July 25, 2013.

Accepted March 26, 2014.

${ }^{1}$ Equal contribution as senior authors.

${ }^{2}$ Corresponding author: michèle.bodmer@vetsuisse.unibe.ch prevalence increased from 27.3 to $56.6 \%$ and the cowlevel prevalence increased from $11.2 \%$ at the beginning of the season to $29.6 \%$ at the end of the season. On 3 different communal operations, Staph. aureus GTBpositive swabs from seasonally employed personnel were identified at the end of the season. The results indicate that Staph. aureus GTB can easily spread in communal operations when cows from different herds of origin are mixed during the summer season. Effective management measures need to be designed to prevent the spread of Staph. aureus GTB in seasonally communal herds.

Key words: epidemiology, Staphylococcus aureus, communal herd, biosecurity

\section{INTRODUCTION}

Staphylococcus aureus is an important agent of contagious mastitis in dairy cows (Olde Riekerink et al., 2008; Barkema et al., 2009) and is associated with major economic loss (Seegers et al., 2003; Hogeveen et al., 2011). Several recent studies from different countries have pointed to a wide variety of mastitis-related subtypes of Staph. aureus with different epidemiological properties (Larsen et al., 2000; Middleton et al., 2002; Jørgensen et al., 2005; Capurro et al., 2010a; Costa et al., 2012; Mitra et al., 2013). Moreover, a few predominant strains of Staph. aureus that are mostly associated with IMI were found to be distributed among dairy herds across various geographic regions (Aarestrup et al., 1997; Cabral et al., 2004; Jørgensen et al., 2005; Smith et al., 2005; Capurro et al., 2010a). In Switzerland, Fournier et al. (2008) identified several genotypes of Staph. aureus that differ in their contagiosity and pathogenicity. Most identified genotypes affected only a few cows in a herd, with often only 1 infected quarter per cow. In contrast, Staph. aureus genotype B (GTB) was found to be associated with high within-herd prevalences and high SCC, indicating an increased contagious and virulence potential compared with other genotypes (Fournier et al., 2008; Graber et al., 2009). According 
to Hagnestam-Nielsen et al. (2009), the highest proportion of milk loss in a herd due to subclinical mastitis is caused by cows of higher parity toward the end of lactation. Most cows going to communal operations are in mid or late lactation at the end of the pasture season. Additionally, Politis and Ng-Kwai-Hang (1988) showed that cheese production is decreased when using high-SCC milk. This applies to communal operations in Switzerland investigated in the present study where raw milk was used for cheese production. Consequently, maximum milk loss exists, leading to decreased cheese production and, therefore, to economic loss.

Cattle movements may enhance the spread of contagious pathogens between dairy herds through transmission between infected and susceptible cows from different herds of origin (Fèvre et al., 2006; Barkema et al., 2009; Mee et al., 2012). Spergser et al. (2013) observed a remarkable dissemination of Mycoplasma bovis in commingled herds grazing on communal pastures. Middleton et al. (2002) reported an increased prevalence of Staph. aureus mastitis in herds purchasing replacement heifers compared with closed herds. Confirming these findings, Kristula et al. (2009) found an increased incidence of Staph. aureus infections in herds of origin after experimentally commingling them with other herds for a limited period of time. Moreover, several studies examined the implementation of biosecurity measures to prevent infectious diseases in dairy farming systems. These measures include, among others, purchasing animals exclusively from farms with a known disease history, temporarily quarantining cows before introducing them into the new herd, and diagnostic testing and prophylactic treatment of purchased cattle (Hoe and Ruegg, 2006; Villarroel et al., 2007; Brennan and Christley, 2012; Mee et al., 2012, Sayers et al., 2013).

Intramammary sites are considered to be the most relevant reservoir for bovine Staph. aureus infections (Barkema et al., 2009). Nevertheless, extramammary sites, such as the skin on the hock and biting flies, were also identified as important reservoirs for Staph. aureus (Capurro et al., 2010b; Roberson et al., 1994). However, isolates obtained from milking personnel were different from isolates obtained from cows affected by mastitis (Roberson et al., 1998; Larsen et al., 2000; Capurro et al., 2010b; Anderson et al., 2012; Mee et al., 2012).

Little is known about the spread of Staph. aureus in seasonally operated, pasture-based communal dairy herds. The aim of the present field study was, therefore, to evaluate the development of Staph. aureus GTB prevalence in communal operations, where cows from different herds of origin were commingled during a summer period. In addition, the environment was investigated as a potential reservoir for Staph. aureus GTB and personnel as potential transmission vectors.

\section{MATERIALS AND METHODS}

\section{Structure of Communal Operations}

Dairy farming in certain regions of Switzerland during the summer months is characterized by mixing cows from different herds of origin on large communal operations where pastures and facilities (i.e., housing, milking equipment) are shared. These operations are owned by associations of farmers mainly living in 1 village. Farmers may bring a selection or their entire dairy herd to these communal pastures where they are milked by seasonally employed personnel, who commonly consist of milking personnel and specially trained cheese-producing employees who also milk cows in times of high workload. This particular farm structure is hereafter defined as communal operation. Traditionally, most cows from a single village are transported together to the communal operation at the beginning of the summer season at a preset date, with individual cows occasionally being brought there later. At the end of the summer season, most cows housed in a communal operation are transported back in 1 batch to their herds of origin at a preset date, although individual cows may return earlier because of an approaching dry period.

\section{Selection of Communal Operations}

A total of 9 different communal operations in the eastern part of Switzerland were investigated in this study. The criterion of communal operations to be selected for the study was the willingness of the owners and the seasonally employed farming personnel to participate in this study. On all communal operations, milking was performed twice daily with various types of milking systems, including low-line milking parlor (side-by-side), pipeline milking systems (tie-stalls), and bucket milking systems. Standard operation procedures concerning milking hygiene and milking routines recommended by the National Mastitis Council (NMC, 1999) guidelines to control contagious mastitis were not put into effect at the included communal operations. Because most cows were not tested for the presence of contagious mastitis pathogens before transport to the communal operations, the grouping of infected cows and milking them last was not part of their milking routine. The milk of all 9 operations was used for raw milk cheese production.

\section{Collection of Milk Samples}

After udders were prepared by the farming personnel, including forestripping and teat cleaning, the research 
team members collected clean composite foremilk samples of all present cows twice at each communal operation. The first sample collection (S1) was performed at the first or second milking after the transport to the communal operation. The second sampling (S2) took place 3 to $7 \mathrm{~d}$ before the end of the communal operation season. Cows arriving at the communal operation later or leaving it earlier than at the preset dates were sampled by the milking personnel using the described protocol at their first milking or at their last milking, respectively. Disposable gloves were worn during sampling and were changed after each animal. Samples were kept at $4^{\circ} \mathrm{C}$ during transport to the laboratory and were subsequently stored at $-20^{\circ} \mathrm{C}$ until further processing.

\section{Collection of Environmental Samples}

Humans and Dogs. The involved personnel were sampled twice: once at S1 and once at S2. Sample collection of personnel consisted of swabbing the inner surfaces of both hands and the medial aspect of both elbow joints, using 1 sterile transport swab (Transwab Amies; Medical Wire \& Equipment Co. Ltd., Wiltshire, UK) for each hand and 1 transport swab for both elbows. The sample collection at S1 was performed before personnel had contact with cows or milk and at S2 immediately before milking. Nasal sampling consisted of gently swabbing both nasal cavities (rolling the swab along the mucosa) with 1 sterile transport swab (Sakwinska et al., 2009). This procedure was also used to collect nasal swabs of herding dogs on the communal operations. Nasal swabs of the dogs present were only collected at S1 to assess whether they could potentially introduce Staph. aureus GTB to the communal dairy herd.

Communal Operation Environment. The milking equipment (internal surface of teat cup liners and rubber milk lines), stable surfaces (food trough, drinking trough, and lying surfaces), and surfaces in the room designated for cheese production and the storage room for milking equipment (wall, floor, sink, and door handle) were sampled before the animals arrived. At least $2 \mathrm{~m}^{2}$ were tested from large surfaces by swabbing them with 1 or 2 sterile cotton swabs moistened with $0.9 \% \mathrm{NaCl}$, as recommended by Agroscope LiebefeldPosieux (Liebefeld, Switzerland; H. U. Graber, unpublished data, 2013). The swabs were held with hemostats previously sterilized using dry heat. After sampling, the swabs were stored in sterile tubes. For all other surfaces, transport swabs with Amies medium (Transwab Amies) were used. All collected material was stored at $4^{\circ} \mathrm{C}$ and processed within $3 \mathrm{wk}$ as proposed by Sakwinska et al. (2010).

\section{Assay for Staph. aureus GTB}

Staphylococcus aureus GTB detection was based on the established procedure of Boss et al. (2011), which showed high sensitivity and specificity and included its further development regarding bacteria preparation as described by Syring et al. (2012). The procedure consisted of 3 main steps: (1) preparation of bacteria, (2) DNA extraction, and (3) real-time quantitative PCR (qPCR) detection of the targets.

Bacteria Preparation from the Samples. In this study, the bacterial preparation of milk using Lactobacillus casei was performed as described by Syring et al. (2012). In brief, milk samples were diluted 1:10 with Chapman medium and incubated at $37^{\circ} \mathrm{C}$ for 18 h. Thereafter, the culture was stored at $-20^{\circ} \mathrm{C}$ until further processing. Swab samples of small surfaces were enriched by incubating them in a $9-\mathrm{mL}$ Chapman medium-filled tube. Cotton swabs from larger surfaces were enriched in $20 \mathrm{~mL}$ or $40 \mathrm{~mL}$, for 1 or 2 swabs, respectively. After incubating for $18 \mathrm{~h}$ at $37^{\circ} \mathrm{C}, 1.5 \mathrm{~mL}$ of the culture was stored at $-20^{\circ} \mathrm{C}$ until further processing.

DNA Extraction. The DNA extraction was performed according to Syring et al. (2012) with the following modifications: the bacterial culture was processed using the mericon DNA Bacteria Plus Kit (Qiagen Instruments AG, Hombrechtikon, Switzerland). In brief, $1 \mathrm{~mL}$ of bacterial culture of milk or swabs was added to $650 \mu \mathrm{L}$ of extraction mix containing $L$. casei $\left(10^{10}\right.$ cfu), Triton X-100 (2\%), and $100 \mathrm{~m} M$ Tris/HCl $(\mathrm{pH}=$ 7.8). After centrifugation $\left(18,000 \times g\right.$ for 5 min at $\left.4^{\circ} \mathrm{C}\right)$, the supernatant was discarded. The bacterial pellet was resolved in $400 \mu \mathrm{L}$ Fast Lysis Buffer (mericon DNA Bacteria Plus Kit) and further processed as described in the manufacturer's instructions. The obtained DNA samples were then used as a template for the qPCR analyses.

$\boldsymbol{q P C R}$. Detection of Staph. aureus GTB was based on PCR for the sea and sed gene and for the GTBtypical polymorphism within the lukE gene (lukEB) with real-time qPCR, as described in detail by Boss et al. (2011). Polymerase chain reaction analysis of swab samples was performed using a LightCycler 480 RealTime PCR instrument (Roche, Basel, Switzerland). However, DNA from all milk samples was analyzed using an Applied Biosystems ViiA 7 Real-Time PCR System with 384-well block (Life Technologies Europe B.V., Zug, Switzerland). Deviating from Boss et al. (2011), the qPCR reactions for the targets (lukEB, sea, and sed) were run in a total volume of $18.75 \mu \mathrm{L}$ containing $1 \times$ Roche LightCycler 480 Probes Master Mix (Roche) complemented with the ROX Reference Dye (LuBioScience GmbH, Lucerne, Switzerland), us- 
ing the appropriate primer and probe concentrations as described by Boss et al. (2011). Finally, $2.6 \mu \mathrm{L}$ of template DNA was added to the qPCR reaction mix. The PCR cycling steps were run according to Boss et al. (2011).

The qPCR analysis for all targets of each sample was performed in duplicate. Results were considered positive if both reactions were positive. If the difference between duplicate samples was $>2$ cycles, the qPCR procedure was repeated. For all targets, a reaction was considered positive if amplification resulted in values exceeding $8.99 \times 10^{3}$ copies per assay, whereas lower sample values were considered negative as described by Syring et al. (2012). Therefore, a standard curve ranging from 10 to $10^{5}$ copies per reaction was used to analyze the data. A positive control DNA extracted from raw milk spiked with Staph. aureus GTB and a no-template control were included for each PCR reaction. If the results of the controls were false positive or false negative, respectively, the data were discarded and the qPCR procedure was repeated. Finally, 3 repetitions of all analyses with questionable results were performed to exclude false-negative and false-positive test results as far as possible.

\section{Statistical Analysis}

Data are expressed as absolute numbers or percentages. The crude within-communal operation prevalence (i.e., not corrected for other factors such as management practices or the cow's age), the crude between-herd of origin prevalence, and the crude cow-level prevalence, including the corresponding $95 \%$ confidence intervals, were calculated using NCSS 2007 software (NCSS LLC, Kaysville, UT).

Alternating logistic regression models (Carey et al., 1993) were built to quantify the effect of covariates on milk samples that were Staph. aureus GTB positive. Alternating logistic regression models take into account the effect of clustering by estimating the logarithm of odds ratios between pairs of responses while simultaneously regressing the binary outcome on covariates (Carey et al., 1993). These so-called pairwise odds ratios quantify how strongly events (i.e., samples being Staph. aureus GTB positive) occur within clusters of data (i.e., within the same cows or within the same herd of origin). For example, the pairwise odds ratio at the herd of origin level is interpreted as the odds for a cow being Staph. aureus GTB positive, given that another cow in the same herd of origin is Staph. aureus GTB positive relative to the odds that this cow is Staph. aureus GTB negative.

Observations made at communal operations $\mathrm{C}$ and $\mathrm{G}$ were excluded from all alternating logistic regres- sion models because no variation was observed in these clusters at S1 (Table 1). For the observations made at the 7 other communal operations, all statistical models accounted for repeated sampling of cows clustering within herds of origin using the LOGOR option in the REPEATED statement of PROC GENMOD in SAS (version 9.3; SAS Institute Inc., Cary, NC). Communal operations were evaluated as a fixed effect in the model. Including the communal operation, rather than the herd of origin, as a cluster effect into the model was considered but the lower quasi-likelihood information criterion value for a null model with herd of origin included as a cluster effect indicated a better model fit compared with a null model with communal operation included as a cluster effect. Two sampling moments were additionally considered as fixed effects in the models. The first binary variable, as the main variable of interest, indicated whether the sample was taken at $\mathrm{S} 1$ or S2. The second binary variable indicated whether the sample was taken when the majority of the cows were sampled or when individual cows were sampled separately. The 3 fixed effects were first tested in univariable regression models and all qualified $(P<0.25)$ for the multivariable regression models. A backward selection process was applied to identify all covariates significantly $(P<0.05)$ contributing to the final multivariable regression model. All models were checked for confounding, which was assumed when the marginal effect estimates changed $25 \%$ or more. Finally, all 2-way interaction terms were evaluated.

\section{RESULTS}

\section{Descriptive Statistics}

Overall, 829 lactating dairy cows from 110 herds of origin pasturing on 9 communal operations were included in the study. The duration of the communal pasture season ranged from 66 to $76 \mathrm{~d}$ (June to September 2012).

In total, 808 lactating cows were sampled at S1, whereas 734 cows were sampled at S2 (Table 1). Twelve cows from 8 herds of origin from communal operation B were sampled out of the preset transport date at S1 because of their late arrival. A further 9 cows (3 cows each from communal operations $\mathrm{B}$ and $\mathrm{E}$, and 1 cow each from communal operations $\mathrm{C}, \mathrm{H}$, and $\mathrm{F}$ ) arrived after the preset transport date and were not sampled at this time. In total, 207 cows returned to their herds of origin before the preset transport date at S2 (Table 1). Composite milk samples were taken from 112 out of 207 of these early-leaving cows. Therefore, 95 cows were not sampled at S2. Nine to 17 herds of origin transported cows to the 9 communal operations. The total number 
Table 1. Within-communal operation (WCO) and between-herd of origin (BHOO) prevalence of Staphylococcus aureus genotype B (GTB) on 9 Swiss communal operations (OP) at the start (S1) and at the end of the communal pasture season (S2)

\begin{tabular}{|c|c|c|c|c|c|c|c|c|c|c|c|c|}
\hline \multirow[b]{3}{*}{$\mathrm{OP}$} & \multicolumn{6}{|c|}{ S1 } & \multicolumn{6}{|c|}{$\mathrm{S} 2$} \\
\hline & \multicolumn{3}{|c|}{ Cow level } & \multicolumn{3}{|c|}{ Herd of origin level } & \multicolumn{3}{|c|}{ Cow level } & \multicolumn{3}{|c|}{ Herd of origin level } \\
\hline & $\mathrm{n}$ & $\mathrm{GTB}+{ }^{1}$ & $\begin{array}{c}\text { WCO } \\
\text { prevalence } \\
(95 \% \text { CI })\end{array}$ & $\mathrm{n}$ & GTB + & $\begin{array}{c}\text { BHOO } \\
\text { prevalence } \\
(95 \% \text { CI })\end{array}$ & $\mathrm{n}$ & GTB+ & $\begin{array}{c}\text { WCO } \\
\text { prevalence } \\
(95 \% \text { CI })\end{array}$ & $\mathrm{n}$ & GTB+ & $\begin{array}{c}\mathrm{BHOO} \\
\text { prevalence } \\
(95 \% \mathrm{CI})\end{array}$ \\
\hline A & 105 & 13 & $\begin{array}{l}12.4 \\
(6.8-20.2)\end{array}$ & 17 & 5 & $\begin{array}{l}29.4 \\
(10.3-56.0)\end{array}$ & 93 & 29 & $\begin{array}{l}31.2 \\
(22-41.6)\end{array}$ & 17 & 10 & $\begin{array}{l}58.8 \\
(32.9-81.6)\end{array}$ \\
\hline B & 85 & 15 & $\begin{array}{l}17.6 \\
(10.2-27.4)\end{array}$ & 17 & 7 & $\begin{array}{l}41.2 \\
(18.4-67.1)\end{array}$ & 78 & 36 & $\begin{array}{l}46.2 \\
(34.8-57.8)\end{array}$ & 16 & 13 & $\begin{array}{l}81.3 \\
(54.4-96.0)\end{array}$ \\
\hline $\mathrm{C}$ & 109 & 0 & $\begin{array}{l}0.0 \\
(0.0-3.3)\end{array}$ & 15 & 0 & $\begin{array}{l}0.0 \\
(0.0-21.8)\end{array}$ & 103 & 1 & $\begin{array}{l}1.0 \\
(0.0-5.3)\end{array}$ & 14 & 1 & $\begin{array}{l}7.1 \\
(0.2-33.9)\end{array}$ \\
\hline $\mathrm{D}$ & 91 & 2 & $\begin{array}{l}2.2 \\
(0.3-7.7)\end{array}$ & 13 & 2 & $\begin{array}{l}15.4 \\
(1.9-45.4)\end{array}$ & 71 & 4 & $\begin{array}{l}5.6 \\
(1.6-13.8)\end{array}$ & 11 & 3 & $\begin{array}{l}27.3 \\
(6.0-61.0)\end{array}$ \\
\hline $\mathrm{E}$ & 70 & 7 & $\begin{array}{l}10.0 \\
(4.1-19.5)\end{array}$ & 10 & 2 & $\begin{array}{l}20.0 \\
(2.5-55.6)\end{array}$ & 62 & 18 & $\begin{array}{l}29.0 \\
(18.2-41.9)\end{array}$ & 10 & 6 & $\begin{array}{l}60.0 \\
(26.2-87.8)\end{array}$ \\
\hline $\mathrm{F}$ & 87 & 18 & $\begin{array}{l}20.7 \\
(12.7-30.7)\end{array}$ & 6 & 3 & $\begin{array}{l}50.0 \\
(11.8-88.2)\end{array}$ & 84 & 43 & $\begin{array}{l}51.2 \\
(40-62.3)\end{array}$ & 6 & 6 & $\begin{array}{l}100 \\
(54.1-100)\end{array}$ \\
\hline G & 86 & 0 & $\begin{array}{l}0.0 \\
(0.0-4.2)\end{array}$ & 8 & 0 & $\begin{array}{l}0.0 \\
(0.0-36.9)\end{array}$ & 72 & 2 & $\begin{array}{l}2.8 \\
(0.0-9.7)\end{array}$ & 8 & 2 & $\begin{array}{l}25.0 \\
(3.2-65.1)\end{array}$ \\
\hline $\mathrm{H}$ & 72 & 28 & $\begin{array}{l}38.9 \\
(27.6-51.1)\end{array}$ & 10 & 6 & $\begin{array}{l}60.0 \\
(26.2-87.8)\end{array}$ & 68 & 49 & $\begin{array}{l}72.1 \\
(59.9-82.3)\end{array}$ & 10 & 10 & $\begin{array}{l}100 \\
(69.2-100)\end{array}$ \\
\hline I & 115 & 9 & $\begin{array}{l}7.8 \\
(3.6-14.3)\end{array}$ & 14 & 5 & $\begin{array}{l}35.7 \\
(12.8-64.9)\end{array}$ & 103 & 35 & $\begin{array}{l}34.0 \\
(24.9-44.0)\end{array}$ & 14 & 9 & $\begin{array}{l}64.3 \\
(35.1-87.2)\end{array}$ \\
\hline Total & 820 & 92 & $\begin{array}{l}11.2 \\
(9.1-13.6)\end{array}$ & 110 & 30 & $\begin{array}{l}27.3 \\
(19.2-36.6)\end{array}$ & 734 & 217 & $\begin{array}{l}29.6 \\
(26.3-33.0)\end{array}$ & 106 & 60 & $\begin{array}{l}56.6 \\
(46.6-66.2)\end{array}$ \\
\hline
\end{tabular}

${ }^{1} \mathrm{GTB}+=$ number of cows being Staph. aureus GTB positive or number of herds of origin having $\geq 1$ cows being Staph. aureus GTB positive. 
of lactating cows per operation ranged between 70 and 115 (Table 1).

Staphylococcus aureus GTB-positive samples taken at S1 were identified in 7 out of 9 communal operations, showing a within-communal operation prevalence of Staph. aureus GTB of 2.2 to $38.9 \%$. Staphylococcus aureus GTB-positive cows were identified in all communal operations at S2. The within-communal operation prevalence then ranged from 1 to $72.1 \%$. The betweenherd of origin prevalence increased from $27.3 \%$ (95\% CI: $19.2-36.6)$ at S1 to $56.6 \%$ (95\% CI: $46.6-66.2)$ at $\mathrm{S} 2$, whereas the prevalence at cow level increased from $11.2 \%(95 \%$ CI: $9.1-13.6)$ at S1 to $29.6 \%$ (95\% CI: 26.3-33.0) at S2 (Table 1).

\section{Alternating Logistic Regression Model}

The results from the final alternating logistic regression model are presented in Table 2. The odds for cows being Staph. aureus GTB positive at S2 was 3.4 times higher than at S1, which was significant. Cows that were sampled separately (because they arrived later or left the communal operation earlier) were 7.7 times more likely to test positive for Staph. aureus GTB than cows sampled at the preset transport date (Table 2). The odds for being Staph. aureus GTB positive was the highest in communal operation $\mathrm{H}$ and the lowest in operation D. The odds for a cow being Staph. aureus GTB positive at S2 was 7.1 times higher if it was also found to be positive at S1. The odds for a cow being Staph. aureus GTB positive was additionally 2.2 times higher if other cows within the same herd of origin were also Staph. aureus GTB positive.

\section{Environmental Samples}

Overall, 120 swabs from 30 persons seasonally employed at the communal operations and 7 nasal swabs of 7 herding dogs were collected at S1. Additionally, 124 swab samples from the inanimate environment were taken at S1. All these swabs were found to be Staph. aureus GTB negative. At S2, 112 swabs were collected from 28 persons seasonally employed on the communal operations. Out of those, 5 swabs collected from 4 employees at 3 different communal operations were positive for Staph. aureus GTB. The pooled swab samples of the medial aspects of the elbows of 1 cheese-producing employee from operation $\mathrm{E}$ and of 1 milker from operation F, respectively, were Staph. aureus GTB positive. Additionally, swabs collected from the palm of both hands of 1 milker and from the palm of the left hand of 1 cheese-producing employee from operation I were identified as Staph. aureus GTB positive.

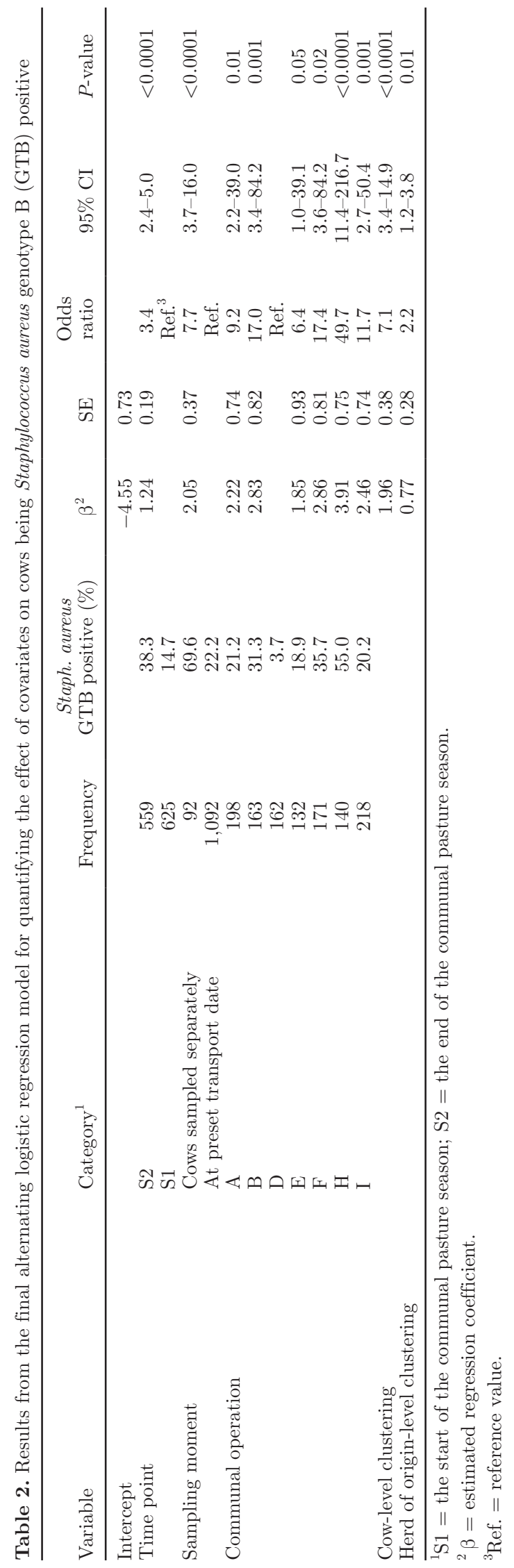

Journal of Dairy Science Vol. 97 No. 7, 2014 


\section{DISCUSSION}

To the best of our knowledge, this was the first study investigating the prevalence of Staph. aureus GTB on communal operations, where cows of different herds of origin were mixed for a limited period of time. The present study demonstrated that Staph. aureus GTB can easily spread in communal operations after commingling different herds of origin without having first established measures designed to minimize the spread of contagious mastitis pathogens during the milking process. The within-communal herd prevalence of all operations increased, and the number of herds of origin affected with Staph. aureus GTB doubled during the communal pasture period. These findings represent further evidence of the contagious nature of Staph. aureus GTB previously described by Graber et al. (2009) and Michel et al. (2011). Our results are similar to those of Middleton et al. (2002) and Kristula et al. (2009), who reported an increased prevalence of Staph. aureus mastitis after mixing heifers of different herds of origin. It is assumed that Staph. aureus GTB continues to spread when cows return to their herds of origin at the end of the season. However, most cows were at the end of their current lactation when returning to their herds of origin and would have most likely received an antimicrobial treatment soon afterward because they needed to be dried off. These treatments are assumed to lower the within-herd of origin prevalence of Staph. aureus GTB, thereby limiting the transmission of this bacterium to susceptible cows within the herd of origin. This biological process has not been investigated in the current study but the doubling of the Staph. aureus GTB between-herd of origin prevalence showed the potential of this pathogen to cause continued herd health problems in the herds of origin at the end of the communal pasture season.

An alternating logistic regression model was used to quantify the effect of covariates on milk samples that were Staph. aureus GTB positive. Differences in the prevalence of Staph. aureus GTB were observed between the communal operations but those did not change over time. The interaction term between communal operation and time point was not significant $(P=0.11)$ and was, therefore, excluded from the final statistical model. This suggests that the overall effect of the management practices had similar consequences on the prevalence of Staph. aureus GTB on all communal operations. Because data on milking systems and milking routine were not recorded for the present study, no risk factor analysis on cow, herd of origin, or communal operation level could be performed to evaluate the effect of management practices on the prevalence of
Staph. aureus GTB in communal operations. However, important management practices, including items related to milking routine and hygiene, would be expected to be of importance for the spread of Staph. aureus IMI within dairy herds (Dufour et al., 2012). Refining these management practices is expected to greatly reduce the transmission of Staph. aureus GTB in communal operations (Barkema et al., 2009; Capurro et al., 2010b; Dufour et al., 2012).

Cows not sampled on the preset sampling date had significantly higher odds of being Staph. aureus GTB positive than cows that were sampled on the preset transport date. This result is not surprising for $\mathrm{S} 2$, as cows left the communal operation earlier because they were about to be dried off. The reasons for early dry off are commonly low milk production or poor udder health, or both, explaining the higher Staph. aureus GTB prevalence within the subgroup of early-leaving cows. Additionally, farmers might have kept cows with a suspicion of a preexisting Staph. aureus GTB infection longer at the farm of origin to avoid milk analysis at $\mathrm{S} 1$ to prevent rejection of positive animals by the farmers' association. However, we can only speculate on this, as no clear evidence existed to prove it.

The Staph. aureus GTB-negative environmental samples and the negative nasal swabs of the herding dogs at the at the beginning of the season indicated that Staph. aureus GTB was neither able to survive during winter in the barn and milking equipment nor after being introduced into the communal dairy herd by the herding dogs. These results support the findings of Roberson et al. (1998) and Anderson et al. (2012), who rarely found housing, water, equipment, and bedding to be Staph. aureus positive, indicating that the transmission of Staph. aureus via the direct environment of the cows was of minor importance. Others found that the hock skin, other body sites close to the mammary gland, and horn flies seemed to be an important reservoir of Staph. aureus (Roberson et al., 1998; Capurro et al., 2010b; Anderson et al., 2012). Furthermore, Zadoks et al. (2002) and Larsen et al. (2000) concluded that humans were not a major reservoir for bovine Staph. aureus IMI. Repeated, intensive contact of the cheeseproducing employees with the contaminated milk might have resulted in colonization of exposed body sites by Staph. aureus GTB at the end of the season. Therefore, Staph. aureus GTB-positive personnel might be one of the factors enhancing the increase in Staph. aureus GTB prevalence. However, it was not possible to evaluate this association in the statistical analysis. Communal operation identification, rather than Staph. aureus GTB-positive personnel, was included as a fixed effect in the model to correct for differences between com- 
munal operations, and this explained all the variation at this hierarchical level. The finding of Staph. aureus GTB-positive employees has to be accounted for when planning biosecurity measures.

Communal operations C and G had low Staph. aureus GTB prevalence at S2 despite their negative Staph. aureus GTB status at S1. This is most likely the result of unreported cattle movements to the respective communal operations during the summer season. Evidence supporting this hypothesis was found retrospectively by consulting the national animal movement database. Many more animal movements were identified using the animal movement database than were being reported for the purpose of the current study. However, most of these unreported movements involved young stock and suckler cows. The movement of lactating cows that were not sampled in the current study seemed, therefore, to be of minor importance but could not be entirely excluded. Another possible cause for the transition of the Staph. aureus GTB status of operations C and $\mathrm{G}$ during the season may have been false-negative test results at S1 (e.g., antibiotic residues present in the milk samples) or false-positive samples at S2. This seems unlikely, however, as 3 repetitions of all analyses with questionable results were performed to exclude false-negative and false-positive test results.

Biosecurity measures that are easy to implement need to be designed to minimize the spread of Staph. aureus among cows in open dairy herds, such as communal operations. Implementing and maintaining hygienic milking practices, such as wearing gloves, forestripping, teat cleaning, and postmilking teat disinfection, can significantly improve microbiological quality of milk and are considered crucial components of any Staph. aureus control program (Barkema et al., 2009; Zucali et al., 2011; Dufour et al., 2012). The results of the current study also highlight the significance of grouping Staph. aureus-infected cows separately and milking them last (Capurro et al., 2010b) or with a separate milking unit to avoid transmission within the herd. To control Staph. aureus GTB in communal operations, both the personnel involved and the milking equipment should be considered as potential transmission vectors.

\section{ACKNOWLEDGMENTS}

This study was supported by a grant of the Canton Graubünden, Switzerland. We thank Urs Härdi (Küblis, Graubünden, Switzerland), the farmers, and all involved personnel on the communal operations for their participation and cooperation, and Svenja Strasser, Sabrina Bütler, and Lukas Kronenberg (ETH Zurich, Zurich, Switzerland) for their assistance in sample collection.

\section{REFERENCES}

Aarestrup, F. M., H. C. Wegener, N. E. Jensen, O. Jonsson, V. Myllys, B. M. Thorberg, S. Waage, and V. T. Rosdahl. 1997. A study of phage- and ribotype patterns of Staphylococcus aureus isolated from bovine mastitis in the Nordic countries. Acta Vet. Scand. $38: 243-252$.

Anderson, K. L., R. Lyman, K. Moury, D. Ray, D. W. Watson, and M. T. Correa. 2012. Molecular epidemiology of Staphylococcus aureus mastitis in dairy heifers. J. Dairy Sci. 95:4921-4930.

Barkema, H. W., M. J. Green, A. J. Bradley, and R. N. Zadoks. 2009 Invited review: The role of contagious disease in udder health. J. Dairy Sci. 92:4717-4729.

Boss, R., J. Naskova, A. Steiner, and H. U. Graber. 2011. Mastitis diagnostics: Quantitative PCR for Staphylococcus aureus genotype B in bulk tank milk. J. Dairy Sci. 94:128-137.

Brennan, M. L., and R. M. Christley. 2012. Biosecurity on cattle farms: A study in north-west England. PLoS ONE 7:e28139.

Cabral, K. G., C. Lämmler, M. Zschöck, H. Langoni, M. E. de Sá, C. Victoria, and A. Da Silva. 2004. Pheno- and genotyping of Staphylococcus aureus, isolated from bovine milk samples from São Paulo State, Brazil. Can. J. Microbiol. 50:901-909.

Capurro, A., A. Aspán, K. Artursson, and K. Persson Waller. 2010a. Genotypic variation among Staphylococcus aureus isolates from cases of clinical mastitis in Swedish dairy cows. Vet. J. 185:188192

Capurro, A., A. Aspán, H. Ericsson Unnerstad, K. Persson Waller, and K. Artursson. 2010b. Identification of potential sources of Staphylococcus aureus in herds with mastitis problems. J. Dairy Sci. 93:180-191.

Carey, V., S. L. Zeger, and P. Diggle. 1993. Modelling multivariate binary data with alternating logistic regressions. Biometrika $80: 517-526$.

Costa, G. M., L. V. Paiva, H. C. P. Figueiredo, A. R. Figueira, U. P. Pereira, and N. Silva. 2012. Population diversity of Staphylococcus aureus isolated from bovine mastitis in Brazilian dairy herds. Res. Vet. Sci. 93:733-735.

Dufour, S., I. R. Dohoo, H. W. Barkema, L. DesCôteaux, T. J. DeVries, K. K. Reyher, J. P. Roy, and D. T. Scholl. 2012. Manageable risk factors associated with the lactational incidence, elimination, and prevalence of Staphylococcus aureus intramammary infections in dairy cows. J. Dairy Sci. 95:1283-1300.

Fèvre, E. M., B. M. de C. Bronsvoort, K. A. Hamilton, and S. Cleaveland. 2006. Animal movements and the spread of infectious diseases. Trends Microbiol. 14:125-131.

Fournier, C., P. Kuhnert, J. Frey, R. Miserez, M. Kirchhofer, T. Kaufmann, A. Steiner, and H. U. Graber. 2008. Bovine Staphylococcus aureus: Association of virulence genes, genotypes and clinical outcome. Res. Vet. Sci. 85:439-448.

Graber, H. U., J. Naskova, E. Studer, T. Kaufmann, M. Kirchhofer, M. Brechbühl, W. Schaeren, A. Steiner, and C. Fournier. 2009. Mastitis-related subtypes of bovine Staphylococcus aureus are characterized by different clinical properties. J. Dairy Sci. 92:1442-1451.

Hagnestam-Nielsen, C., U. Emanuelson, B. Berglund, and E. Strandberg. 2009. Relationship between somatic cell count and milk yield in different stages of lactation. J. Dairy Sci. 92:3124-3133.

Hoe, F. G. H., and P. L. Ruegg. 2006. Opinions and practices of Wisconsin dairy producers about biosecurity and animal well-being. J. Dairy Sci. 89:2297-2308.

Hogeveen, H., K. Huijps, and T. Lam. 2011. Economic aspects of mastitis: New developments. N. Z. Vet. J. 59:16-23.

Jørgensen, H. J., T. Mørk, D. A. Caugant, A. Kearns, and L. M. Rørvik. 2005. Genetic variation among Staphylococcus aureus strains from Norwegian bulk milk. Appl. Environ. Microbiol. 71:83528361 .

Kristula, M. A., M. E. Fecteau, B. I. Smith, S. Young, and S. C. Rankin. 2009. Evaluation of the risk of transmitting Staphylococcus aureus strains between replacement heifers through commingling at a heifer-rearing facility. Bovine Pract. 43:75-83.

Larsen, H. D., K. H. Sloth, C. Elsberg, C. Enevoldsen, L. H. Pedersen, N. H. R. Eriksen, F. M. Aarestrup, and N. E. Jensen. 2000. The 
dynamics of Staphylococcus aureus intramammary infection in nine Danish dairy herds. Vet. Microbiol. 71:89-101.

Mee, J. F., T. Geraghty, R. O'Neill, and S. J. More. 2012. Bioexclusion of diseases from dairy and beef farms: Risks of introducing infectious agents and risk reduction strategies. Vet. J. 194:143-150.

Michel, A., C. Syring, A. Steiner, and H. U. Graber. 2011. Intramammary infections with the contagious Staphylococcus aureus genotype B in Swiss dairy cows are associated with low prevalence of coagulase-negative staphylococci and Streptococcus spp. Vet. J. 188:313-317.

Middleton, J. R., L. K. Fox, J. M. Gay, J. W. Tyler, and T. E. Besser. 2002. Use of pulsed-field gel electrophoresis for detecting differences in Staphylococcus aureus strain populations between dairy herds with different cattle importation practices. Epidemiol. Infect. 129:387-395.

Mitra, S. D., D. Velu, M. Bhuvana, N. Krithiga, A. Banerjee, R. Shome, H. Rahman, S. K. Ghosh, and B. R. Shome. 2013. Staphylococcus aureus spa type t267, clonal ancestor of bovine subclinical mastitis in India. J. Appl. Microbiol. 114:1604-1615.

NMC (National Mastitis Council). 1999. Laboratory Handbook on Bovine Mastitis. Rev. ed. National Mastitis Council Inc., Madison, WI.

Olde Riekerink, R. G. M., H. W. Barkema, D. F. Kelton, and D. T. Scholl. 2008. Incidence rate of clinical mastitis on Canadian dairy farms. J. Dairy Sci. 91:1366-1377.

Politis, I., and K. F. Ng-Kwai-Hang. 1988. Association between somatic cell count of milk and cheese-yielding capacity. J. Dairy Sci. $71: 1720-1727$

Roberson, J. R., L. K. Fox, D. D. Hancock, J. M. Gay, and T. E. Besser. 1994. Ecology of Staphylococcus aureus isolated from various sites on dairy farms. J. Dairy Sci. 77:3354-3364.

Roberson, J. R., L. K. Fox, D. D. Hancock, J. M. Gay, and T. E. Besser. 1998. Sources of intramammary infections from Staphylococcus aureus in dairy heifers at first parturition. J. Dairy Sci. 81:687-693.

Sakwinska, O., D. S. Blanc, C. Lazor-Blanchet, M. Moreillon, M. Giddey, and P. Moreillon. 2010. Ecological temporal stability of Staphylococcus aureus nasal carriage. J. Clin. Microbiol. 48:2724-2728.

Sakwinska, O., G. Kuhn, C. Balmelli, P. Francioli, M. Giddey, V. Perreten, A. Riesen, F. Zysset, D. S. Blanc, and P. Moreillon. 2009.
Genetic diversity and ecological success of Staphylococcus aureus strains colonizing humans. Appl. Environ. Microbiol. 75:175-183.

Sayers, R. G., G. P. Sayers, J. F. Mee, M. Good, M. L. Bermingham, J. Grant, and P. G. Dillon. 2013. Implementing biosecurity measures on dairy farms in Ireland. Vet. J. http://dx.doi.org/10.1016/j. tvjl.2012.11.017.

Seegers, H., C. Fourichon, and F. Beaudeau. 2003. Production effects related to mastitis and mastitis economics in dairy cattle herds. Vet. Res. 34:475-491.

Smith, E. M., L. E. Green, G. F. Medley, H. E. Bird, L. K. Fox, Y. H. Schukken, J. V. Kruze, A. J. Bradley, R. N. Zadoks, and C. G. Dowson. 2005. Multilocus sequence typing of intercontinental bovine Staphylococcus aureus isolates. J. Clin. Microbiol. 43:47374743

Spergser, J., K. Macher, M. Kargl, I. Lysnyansky, and R. Rosengarten. 2013. Emergence, re-emergence, spread and host species crossing of Mycoplasma bovis in the Austrian Alps caused by a single endemic strain. Vet. Microbiol. 164:299-306.

Syring, C., R. Boss, M. Reist, M. Bodmer, J. Hummerjohann, P. Gehrig, and H. U. Graber. 2012. Bovine mastitis: The diagnostic properties of a PCR-based assay to monitor the Staphylococcus aureus genotype B status of a herd, using bulk tank milk. J. Dairy Sci. 95:3674-3682

Villarroel, A., D. A. Dargatz, V. M. Lane, B. J. McCluskey, and M. D. Salman. 2007. Suggested outline of potential critical control points for biosecurity and biocontainment on large dairy farms. J. Am. Vet. Med. Assoc. 230:808-819.

Zadoks, R. N., W. B. van Leeuwen, D. Kreft, L. K. Fox, H. W. Barkema, Y. H. Schukken, and A. van Belkum. 2002. Comparison of Staphylococcus aureus isolates from bovine and human skin, milking equipment, and bovine milk by phage typing, pulsed-field gel electrophoresis, and binary typing. J. Clin. Microbiol. 40:38943902

Zucali, M., L. Bava, A. Tamburini, M. Brasca, L. Vanoni, and A. Sandrucci. 2011. Effects of season, milking routine and cow cleanliness on bacterial and somatic cell counts of bulk tank milk. J. Dairy Res. 78:436-441. 